\title{
Evaluation of the Development of National Higher Education System Based on TOPSIS and Entropy Weight Method
}

\author{
Xiangyu LI, Jie SHEN ${ }^{1}$ \\ Wuhan Business University, China
}

\begin{abstract}
By using the index data from 14 countries with relatively mature higher education development in the UNESCO database, this paper establishes a comprehensive evaluation system for the health status of the higher education system from 2010 to 2019.By establishing the "vision" model, the optimal level under the five dimensions of the current higher education system is established.By comparing the scores of China and other countries in five dimensions, it is found that there is still a large gap between China's higher education system and the world leading level in corresponding fields in talent training, scientific research and economic development, while the external environment and international exchanges are expected to catch up with or even exceed the world advanced level in the short term.
\end{abstract}

Keyword. Development of higher education, entropy weight method, TOPSIS method, "Vision" model.

\section{Introduction}

A healthy and sustainable higher education system is often a symbol of a country's cultural soft power. However, every country's higher education system has its advantages and disadvantages. The global spread of COVID-19 prompted countries to reflect on the pros and cons of their national higher education system, and furthermore, improve the higher education system. It is of great significance to establish a reasonable higher education system and put forward targeted policies to upgrade the status quo.Considering the above realistic background, this paper establishes a mathematical model to evaluate the health status of national higher education system, applies it to several representative countries, and selects China's higher education system as the research object for further analysis; The above model is used to measure the health of China's higher education system, and an achievable and reasonable vision is put forward according to the analysis results.

\section{Literature Review}

The main countries in North America, Europe, East Asia and Australia have developed their higher education early, accumulated a lot and have a good reputation, forming a 
good inertia of higher education development. While the countries in Africa, South Asia and South America have lower quality of higher education internationalization with a small scale, which makes it difficult to directly realize large-scale talent flow towards the powerful countries in higher education. China is in the middle and plays a major role as a transit country of international talent flow in the world. However, this role has also brought many problems, such as the imbalance of investment and harvest in the higher education system, the emphasis on quantity over quality in internationalization, and so on ${ }^{[1]}$.

Different from the higher education before the epidemic, the emerging online education may become a new module of the internationalization of higher education system, and distance teaching will become an auxiliary way of offline courses and an important way for international students in the future ${ }^{[2]}$. However, online education is still difficult to meet the needs of high-quality education ${ }^{[3]}$.

At the same time, with the aggravation of the global economic recession, many countries and students are unable or unwilling to raise funds for expensive higher education. According to the World Education Service Survey, 79\% of the prospective students expect that their economic situation will be negatively affected by the epidemic; $43 \%$ of the students worry that they will no longer be able to afford to study in the United States ${ }^{[4]}$.At present, more and more international students $(57 \%)$ are delaying or canceling their overseas study plans ${ }^{[5]}$.

\section{Data Sources and Data Description}

\subsection{Data Sources}

In order to more objectively and accurately find the factors affecting the development of higher education system and accurately measure the influence degree of key influencing factors, this paper makes an in-depth study on the indicators of the comprehensive evaluation index system from 2010 to 2019.The selected data are from the UNESCO database ${ }^{[6]}$.

\subsection{Data Description}

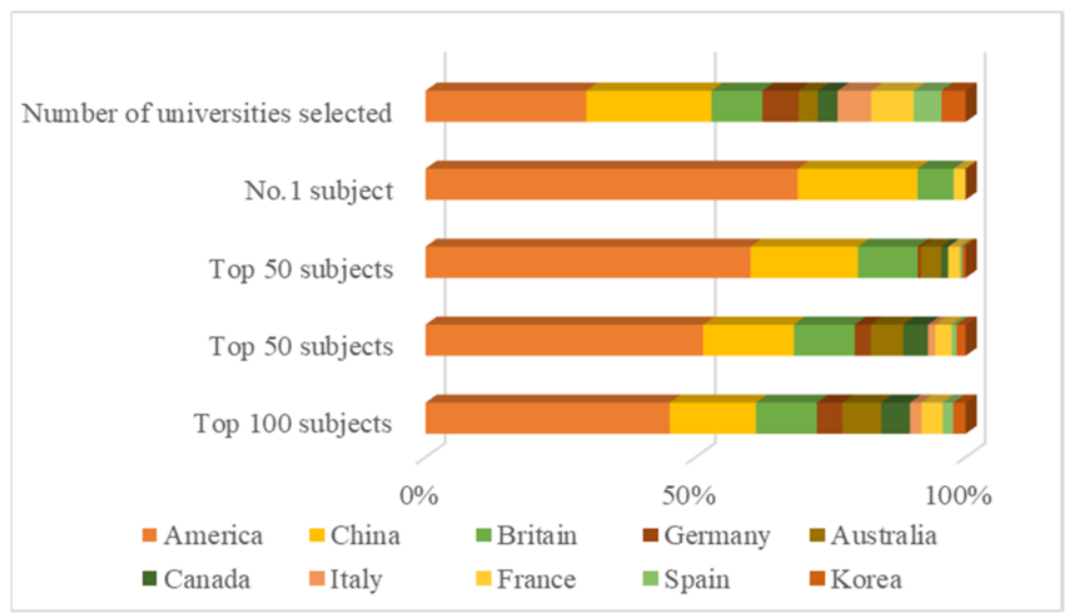

Figure 1. Ranking of world-class disciplines in Soft Science 
It can be seen from figure 1 that the United States, China and the United Kingdom have obvious advantages in the number of world-class disciplines and the number of world-class universities. In addition, as the world's major developed countries, the United States, the United Kingdom, Germany, Italy, Australia, Canada and France have the leading higher education health status in the world; China, South Korea, Singapore, India and Japan, with rapid economic development and obvious internationalization trend of higher education, have both progress and lag in the development of higher education; while Bangladesh, Spain and other countries have the same development status. The development level of higher education in China is relatively general. Based on the above analysis, we select the representative countries in these three categories to make a detailed analysis of the health of their higher education ${ }^{[7]}$.

\subsection{Comprehensive Evaluation Index System Model of National Higher Education Health}

Qualitative indicators are seldom used to evaluate the health of a country's higher education, while quantitative indicators are often used to objectively describe the development level of a country's higher education. According to the following reasons, we will make an objective and comprehensive evaluation on the health of higher education in the selected countries from the 5 dimensions of personnel training, scientific research, economic development, surrounding environment and international exchanges.

Table 1. Comprehensive evaluation index system of health of national higher education

\begin{tabular}{|c|c|c|c|c|}
\hline $\begin{array}{l}\text { First level } \\
\text { indicators }\end{array}$ & $\begin{array}{l}\text { Secondary } \\
\text { indicators }\end{array}$ & Selected data & $\begin{array}{c}\text { Index } \\
\text { weight }\end{array}$ & $\begin{array}{l}\text { Index } \\
\text { attribute }\end{array}$ \\
\hline \multirow[t]{5}{*}{$\begin{array}{l}\text { Personnel } \\
\text { training }(0.25)\end{array}$} & $\begin{array}{l}\text { Vocational } \\
\text { education }\end{array}$ & $\begin{array}{l}\text { Proportion of students who have } \\
\text { received vocational courses }\end{array}$ & 0.030 & + \\
\hline & $\begin{array}{l}\text { Education } \\
\text { level }\end{array}$ & $\begin{array}{l}\text { Proportion of college students and } \\
\text { above }\end{array}$ & 0.083 & + \\
\hline & & $\begin{array}{l}\text { Proportion of undergraduates and } \\
\text { above }\end{array}$ & 0.048 & + \\
\hline & & $\begin{array}{l}\text { Proportion of students with master's } \\
\text { degree or above }\end{array}$ & 0.043 & + \\
\hline & & Proportion of doctoral students & 0.048 & + \\
\hline \multirow[t]{2}{*}{$\begin{array}{c}\text { Scientific } \\
\text { research }(0.25)\end{array}$} & $\begin{array}{c}\mathrm{R} \& \mathrm{D} \\
\text { personnel }\end{array}$ & $\begin{array}{l}\text { Proportion of R \& D personnel in } \\
\text { Higher Education }\end{array}$ & 0.063 & + \\
\hline & $\begin{array}{l}\text { Innovation } \\
\text { incentive }\end{array}$ & $\begin{array}{l}\text { The proportion of the lack of } \\
\text { innovative talents hindering }\end{array}$ & 0.188 & - \\
\hline \multirow[t]{3}{*}{$\begin{array}{c}\text { Economic } \\
\text { development }(0.2)\end{array}$} & $\begin{array}{c}\text { Capital } \\
\text { expenditure }\end{array}$ & Proportion of capital expenditure & 0.020 & + \\
\hline & $\begin{array}{l}\text { Government } \\
\text { support }\end{array}$ & $\begin{array}{l}\text { Initial government funding for each } \\
\text { college student }\end{array}$ & 0.120 & + \\
\hline & Staff incentive & Proportion of staff salary & 0.060 & + \\
\hline \multirow[t]{2}{*}{$\begin{array}{c}\text { Surrounding } \\
\text { environment }(0.15)\end{array}$} & Social security & $\begin{array}{l}\text { Number of attacks on personnel of } \\
\text { student institutions }\end{array}$ & 0.120 & - \\
\hline & School safety & $\begin{array}{l}\text { Proportion of bullied students in } \\
\text { recent year }\end{array}$ & 0.030 & - \\
\hline \multirow[t]{2}{*}{$\begin{array}{c}\text { International } \\
\text { exchange }(0.15)\end{array}$} & $\begin{array}{l}\text { Study abroad } \\
\text { service }\end{array}$ & $\begin{array}{l}\text { Net flow of international floating } \\
\text { students }\end{array}$ & 0.021 & + \\
\hline & $\begin{array}{l}\text { Academic } \\
\text { exchange }\end{array}$ & Number of world class universities & 0.129 & + \\
\hline
\end{tabular}




\subsection{A Model for Measuring the Health Status of Higher Education in Any Country}

In this paper, by constructing the comprehensive evaluation index system of national higher education health shown in table 1, and using the secondary index data of 14 countries in 3.3, the mathematical model of national higher education development health is established based on the superior and inferior solution distance method and entropy weight value method. The general steps are as follows:

\subsubsection{The Weight of 14 Secondary Indicators in Five Dimensions is Determined Based on Entropy Weight Method}

Weight is used to measure the relative importance of each secondary index, which directly affects the accuracy of health evaluation of a country's higher education system. Information entropy can reflect the information contribution of secondary indicators to the overall evaluation, and its size is related to the evaluation object [8]. In this paper, 14 secondary indicators data from 14 countries are taken as samples, and the weight of each secondary indicator is obtained. The specific results are shown in table 1.

\subsubsection{Determination of Measurement Index Score of National Higher Education System Based on Superior and Inferior Solution Distance Method}

Due to the differences in the dimensions of each evaluation index, the contribution to the health of higher education in a country is also different. Firstly, we need to standardize and normalize the index data according to equation (1).

$$
Z_{i j}=\frac{x_{i j}{ }^{*}}{\sqrt{\sum_{i=1}^{n} X_{i j}{ }^{* 2}}}
$$

For the above quantitative index, it is transformed into dimensionless value $Z_{i j}$ of a between $0-1$ for the forward and standardized methods. This can make sure that the positive indicators (such as the secondary indicators of talent training and scientific research) and the reverse indicators (two secondary indicators in the surrounding environment) show a trend. When the value increases, it indicates that the better the health of higher education in a country, the greater the contribution to the health of the higher education system in a country.

\subsubsection{Index Weight Determination Based on Weighted Calculation Method}

Suppose there are $m$ objects to be evaluated and $n$ evaluation indexes, then the information entropy value $H$ of $j$ and weight value $C$.

$$
H_{j}=-C \sum_{i=1}^{m} p_{i j} \ln \left(p_{i j}\right),(j=1,2, \cdots, n)
$$




$$
\begin{gathered}
p_{i j}=\frac{S_{i j}}{\sum_{i=1}^{m} S_{i j}} \\
\omega_{j}=\frac{\left(1-H_{j}\right)}{\sum_{j=1}^{n}\left(1-H_{j}\right)}
\end{gathered}
$$

In the formula above, $\left(C=\frac{1}{\ln (m)}\right.$, which is the adjustment coefficient.), $0 \leqslant H \leqslant 1$.

In order to better propose targeted policies and implementation programs, the target variable $\mathrm{HEH}($ Health of higher education) is introduced.

$$
H E H=\sum_{i=1}^{n} W_{i} \cdot H E F_{i}
$$

Similarly, according to the basic principle of the national education health comprehensive evaluation index system established above, this paper introduces RT, SR, ED, DEand IS five primary index variables to simplify the analysis. The calculation method is as follows:

$$
\left\{\begin{array}{l}
H E F_{1}=R T=\sum_{j=1}^{m} \alpha_{R T_{j}} \cdot r_{R T_{j}} \\
H E F_{2}=S R=\sum_{j=1}^{m} \alpha_{S R_{j}} \cdot r_{S R_{j}} \\
H E F_{3}=E D=\sum_{j=1}^{m} \alpha_{E D_{j}} \cdot r_{E D_{j}} \\
H E F_{4}=D E=\sum_{j=1}^{m} \alpha_{D E_{j}} \cdot r_{D E_{j}} \\
H E F_{5}=I S=\sum_{j=1}^{m} \alpha_{I S_{j}} \cdot r_{I S_{j}}
\end{array}\right.
$$

In the above formula, $\alpha$ and $r$ are the first level index data and corresponding weight of health of higher education system respectively.

The calculation results are shown in table 1 . 
3.4.4 Country Classification of Health of Higher Education System Based on System Clustering Method

According to the five dimension measurement indicators of 14 countries selected above, SPSS software and systematic clustering method are used to cluster the above index samples.

In this paper, the method of systematic clustering is deviation square.

If the weight matrix is $w_{i}$, the following three conditions must be satisfied:

1) The weight coefficient $w_{i}$ is negatively correlated with the Square $\left(x_{i}-\bar{x}\right)^{2}$ of the deviation;

2) Let the comprehensive weight estimate be $c$. Then it converges to the comprehensive weight coefficient $X$ in probability. Now the weight function is constructed:

$$
\begin{gathered}
w_{i}=(n-1)^{*} s^{2}-\frac{\left(x_{i}-\bar{x}\right)^{2}}{\left((n-1)^{2 *} s^{2}\right)} \\
s^{2}=\frac{\sum_{i=1}^{n}\left(x_{i}-\bar{x}\right)^{2}}{(n-1)^{2}}
\end{gathered}
$$

3) The normalization condition:

$$
\sum_{i=1}^{n} w_{i}=1
$$

After obtaining the weight function according to the overall data, the classification results of higher education health in 14 countries can be obtained based on the quantitative index data.

According to the above basic principles, SPSS was used to cluster, and the cluster pedigree is shown in figure 3 .

\subsection{The Results of the Health Evaluation Model of National the Higher Education System and the "Vision" Model}

\subsubsection{Health of China's Higher Education System}

Compared with figure 2, as the second country in the number of world-class disciplines, China's external environment index is ahead of other countries, with a single score of 0.0818 , and the international exchange index score is second only to the United States, reaching 0.0945. However, its talent cultivation, scientific research and economic development are not satisfactory. As a result, the comprehensive score of health of China's higher education system is low. 


\begin{tabular}{|c|c|c|c|c|c|}
\hline Descending sort & Personnel training & Descending sort & Scientific research & Descending sort & Economic development \\
\hline \multirow{2}{*}{$\begin{array}{l}\text { America } \\
\text { Singapore }\end{array}$} & 0.1276 & \multirow{2}{*}{$\begin{array}{c}\text { America } \\
\text { Spain }\end{array}$} & 0.0968 & \multirow{2}{*}{$\begin{array}{c}\text { America } \\
\text { India }\end{array}$} & 0.2802 \\
\hline & 0.1046 & & 0.096 & & 0.093 \\
\hline Britain & 0.1006 & \multirow{4}{*}{$\begin{array}{c}\text { Singapore } \\
\text { Italy } \\
\text { Britain } \\
\text { France }\end{array}$} & 0.0937 & \multirow{2}{*}{$\begin{array}{l}\text { Singapore } \\
\text { Canada }\end{array}$} & 0.0747 \\
\hline Canada & 0.0979 & & 0.0898 & & 0.0694 \\
\hline Australia & 0.0926 & & 0.0865 & \multirow{2}{*}{$\begin{array}{c}\text { Spain } \\
\text { Bangladesh }\end{array}$} & 0.0665 \\
\hline Germany & 0.0875 & & 0.0819 & & 0.0605 \\
\hline Spain & 0.0796 & Japan & 0.08 & Germany & 0.0567 \\
\hline Japan & 0.0781 & \multirow{2}{*}{$\begin{array}{l}\text { Germany } \\
\text { Canada }\end{array}$} & 0.0785 & \multirow{2}{*}{ Australia } & 0.0535 \\
\hline France & 0.0626 & & 0.0759 & & 0.0533 \\
\hline Korea & 0.062 & Korea & 0.0738 & France & 0.0504 \\
\hline Italy & 0.0479 & \multirow{2}{*}{$\begin{array}{c}\text { Australia } \\
\text { Banoladesh }\end{array}$} & 0.0704 & Japan & 0.0444 \\
\hline India & 0.0327 & & 0.0452 & Korea & 0.0432 \\
\hline \multirow{2}{*}{$\begin{array}{c}\text { Bangladesh } \\
\text { China }\end{array}$} & 0.0233 & \multirow{2}{*}{$\begin{array}{l}\text { India } \\
\text { China }\end{array}$} & 0.0282 & \multirow{2}{*}{$\begin{array}{l}\text { Italy } \\
\text { China }\end{array}$} & 0.0415 \\
\hline & 0.0029 & & 0.0034 & & 0.0127 \\
\hline Descending sort & Surrounding environment & Descending sort & International exchange & Descending sort & Score situation \\
\hline \multirow{2}{*}{$\begin{array}{l}\text { Spain } \\
\text { Italy }\end{array}$} & 0.0933 & \multirow{2}{*}{$\begin{array}{l}\text { America } \\
\text { China }\end{array}$} & 0.1831 & \multirow{2}{*}{$\begin{array}{l}\text { America } \\
\text { Spain }\end{array}$} & 0.7635 \\
\hline & 0.093 & & 0.0945 & & 0.395 \\
\hline \multirow{2}{*}{$\begin{array}{c}\text { Korea } \\
\text { Germany }\end{array}$} & 0.0887 & Britain & 0.0853 & Britain & 0.3887 \\
\hline & 0.085 & France & 0.0747 & Canada & 0.3789 \\
\hline China & 0.0818 & Germany & 0.0693 & Singapore & 0.3789 \\
\hline France & 0.0799 & Australia & ] 0.0682 & Germany & 0.377 \\
\hline America & 0.0758 & Italy & 0.0632 & France & 0.3495 \\
\hline Japan & 0.0751 & Canada & 0.0612 & Australia & 0.3413 \\
\hline Canada & 0.0745 & Spain & 0.0596 & Italy & $0] 3354$ \\
\hline Britain & 0.063 & Japan & 0.0539 & Japan & 0,3315 \\
\hline Australia & 0.0566 & Korea & 0.053 & Korea & 0.3207 \\
\hline Singapore & 0.0558 & Singapore & 0.0501 & Bangladesh & 0.2292 \\
\hline Bangladesh & 0.0531 & Bangladesh & 0.0471 & India & 0.2154 \\
\hline India & 0.0245 & India & 0.037 & China & \begin{tabular}{|l}
$\square$ \\
$\square$
\end{tabular} \\
\hline
\end{tabular}

Figure 2. The descending color scale ranking of health indicators of higher education system in 14 countries

\subsubsection{Establishment of "Vision" Model}

In view of the evaluation of the health of higher education system in 14 selected countries and the dilemma of the specific health of China's higher education system in 14 selected countries, we establish a "vision" model as a better goal for China's higher education system in the future. The "vision" model can be summarized as follows:

$$
H E H_{\max }=\sum_{i=1}^{n} r_{i} \cdot \max \left\{H E F_{i}\right\}
$$

\section{Research Conclusion}

4.1. The Results of the Health Evaluation Model of National Higher Education System

\begin{tabular}{ccccccc} 
& $\begin{array}{c}\text { Personnel } \\
\text { training }\end{array}$ & $\begin{array}{c}\text { Scientific } \\
\text { research }\end{array}$ & $\begin{array}{c}\text { Economic } \\
\text { development }\end{array}$ & $\begin{array}{c}\text { Surrounding } \\
\text { environment }\end{array}$ & $\begin{array}{c}\text { International } \\
\text { exchange }\end{array}$ & $\begin{array}{c}\text { Score } \\
\text { situation }\end{array}$ \\
$\begin{array}{c}\text { Index } \\
\text { weight }\end{array}$ & 0.2500 & 0.2500 & 0.2000 & 0.1500 & 0.1500 & 1.0000 \\
America & 0.1276 & 0.0968 & 0.2802 & 0.0758 & 0.1831 & 0.1510 \\
China & 0.0000 & 0.0000 & 0.0127 & 0.0818 & 0.0945 & 0.0290 \\
Britain & 0.1006 & 0.0865 & 0.0533 & 0.0630 & 0.0853 & 0.0797 \\
Germany & 0.0875 & 0.0785 & 0.0567 & 0.0850 & 0.0693 & 0.0760 \\
Australia & 0.0926 & 0.0704 & 0.0535 & 0.0566 & 0.0682 & 0.0702 \\
\hline
\end{tabular}




\begin{tabular}{|c|c|c|c|c|c|c|}
\hline Canada & 0.0979 & 0.0759 & 0.0694 & 0.0745 & 0.0612 & 0.0777 \\
Italy & 0.0479 & 0.0898 & 0.0415 & 0.0930 & 0.0632 & 0.0662 \\
France & 0.0626 & 0.0819 & 0.0504 & 0.0799 & 0.0747 & 0.0694 \\
Spain & 0.0796 & 0.0960 & 0.0665 & 0.0933 & 0.0596 & 0.0801 \\
Korea & 0.0620 & 0.0738 & 0.0432 & 0.0887 & 0.0530 & 0.0638 \\
Japan & 0.0781 & 0.0800 & 0.0444 & 0.0751 & 0.0539 & 0.0678 \\
India & 0.0327 & 0.0282 & 0.0930 & 0.0245 & 0.0370 & 0.0431 \\
Bangladesh & 0.0262 & 0.0486 & 0.0605 & 0.0531 & 0.0471 & 0.0458 \\
Singapore & 0.1046 & 0.0937 & 0.0747 & 0.0558 & 0.0501 & 0.0804
\end{tabular}

Figure 3. Color scale chart of health score of national higher education system

According to the color chart, it is not difficult to see that the total score of the health of the American higher education system is 0.7635 , which is in an absolutely dominant position among the selected 14 countries. Scores of Scientific Research, Personnel Training, Economic Development and International Exchange of the four first level indicators reach $0.1276,0.0968,0.2802$ and 0.1831 respectively, which is in the leading level. Compared with figure 2, China, as the country with the second largest number of first-class disciplines in the world, is ahead of other countries in terms of External Environment indicators, with a single score of 0.0818 and an International Exchange index score of 0.0945 , second only to the United States. However, its three indicators of Personnel Training, Scientific Research and Economic Development are not satisfactory. As a result, the comprehensive score of health of China's higher education system is weak.

According to the analysis of figure 2 and figure 3, this paper conducts two-dimensional cluster analysis on 14 countries based on the score of five first level indicators, and the results are shown in figure 4.

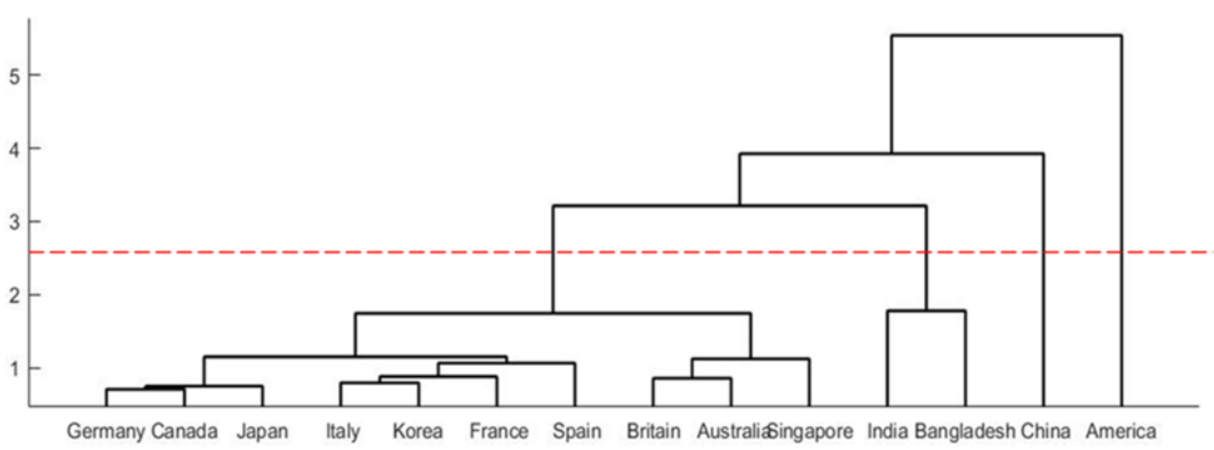

Figure 4. Cluster analysis results of health of higher education system in 14 countries

Taking the red dotted line as the division standard, 14 countries are divided into four categories. The comprehensive status of higher education in the four categories is shown in figure 4. 


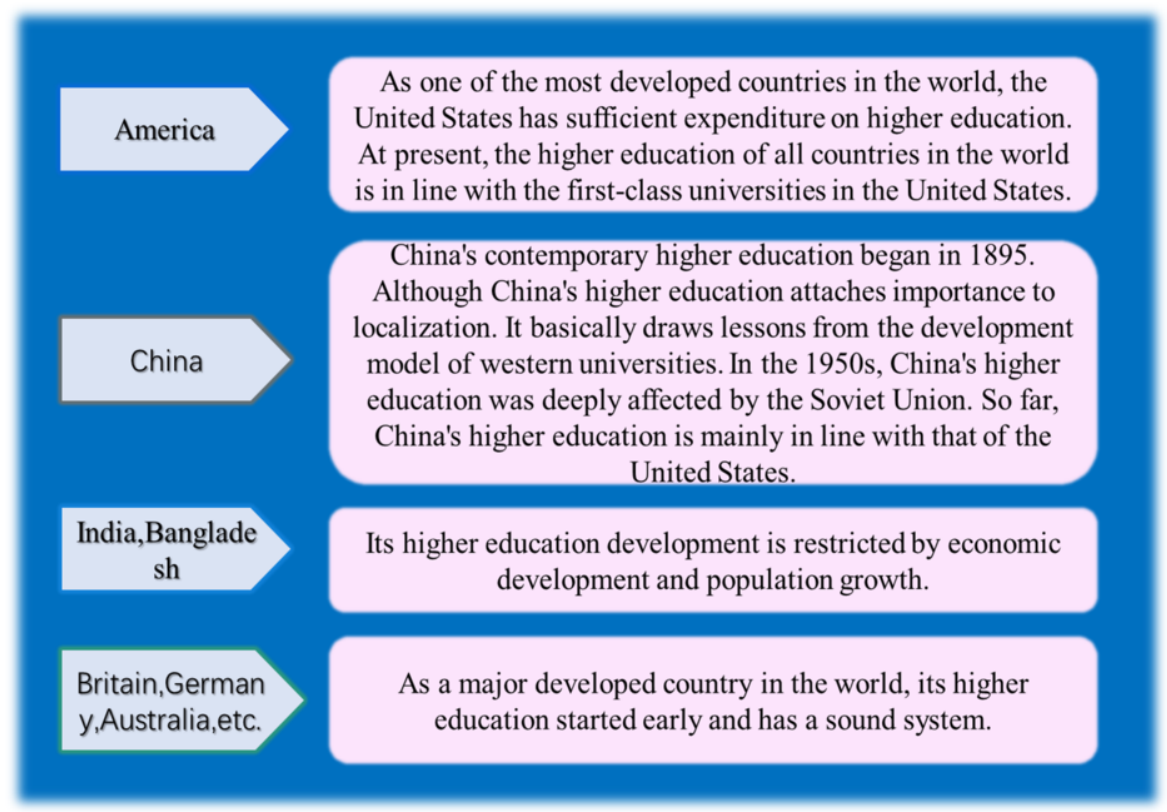

Figure 5. Health status of higher education system in four countries

As the second largest economy and the first largest developing country in the world, China's first level indicators of the higher education system have both obvious advantages and disadvantages. To sum up, as a successful transition economy, the health of China's higher education system does not entirely adapt to its economic status. The dilemma of China's higher education development and the corresponding solutions is worthy of our in-depth discussion. Therefore, we choose China as the target of the following modeling and analysis to make suggestions for the sustainable development of its higher education system (figure 5).

\subsection{The Solution Result of "Vision" Model}

According to the method of building "vision" model in 3.5, we build "vision" model and solve the score level that China should strive to achieve under five dimensions. Under these five dimensions, the visualization results of the comparison between the idealized results of the "vision" model and China's current scores are shown in figure 6.

\begin{tabular}{|c|c|c|}
\hline First level indicators & Scoring in China & Scoring in the vision model \\
\hline Personnel training & 0.0029 & 0.1276 \\
Scientific research & 0.0034 & 0.0968 \\
\hline Economic development & 0.0127 & 0.2802 \\
\hline Surrounding environment & 0.0818 & 0.0933 \\
\hline International exchange & 0.0945 & 0.1831 \\
\hline
\end{tabular}

Figure 6. Visualization of comparison results between China's current situation score and "vision"

As can be seen from figure 6, China's higher education system still lags far behind the world's leading level in personnel training, scientific research and economic development in its corresponding fields, while the external environment and 
international exchanges are expected to catch up with or even surpass the world's advanced level in a short time.

\section{Acknowledgment}

This paper is partially supported by collaborative education project of industry university cooperation of the China Ministry of Education (202101056003).

\section{References}

[1] Liu Jin, Lin Songyue, Song Wen. "Brexit": Dilemma of internationalization of British higher education and opportunities for China [J]. Journal of Beijing University of Aeronautics and Astronautics (SOCIAL SCIENCE EDITION), 2021,34 (01): 143-151

[2] Yang Huiyu and COVID-19: prospects for internationalization of higher education [J]. Jiangsu higher education, 2021 (01): 69-73.

[3] Xu Xiaozhou, Kan Yue. Stepping into the New Globalization -- challenges and Countermeasures of China's education opening to the outside world in the new era [J]. Education research, 2021,42 (01): 129-137

[4] Schulmann,P.Perfect Storm:The Impact of the Coronavirus Crisis on International Student Mobility to the United States [EB/OL].https://wenr.wes.org/2020/05/perfect -storm-the-im-pact-of-the-coronaviruscrisis-on-internationalstudent-mobility-to-the-united-states.2020-05-26.

[5] Studyportals.Impact of COVID-19 on International Student Perceptions[EB/OL]. https://studyportals.com/intelligence/the -impact-of-covid-19-on-international-students-perceptions/ 2020-08-11.

[6] UNESCO UIs database [DB / OL]. [2021-02-7] http://data.uis.unesco.org/

[7] Soft science. 2020 soft science world class discipline ranking method [EB / OL]. [2021-02-7] http://k.sina.com.cn/article_5359069294_13f6ce86e01900 vkue.html 